一論 文-

\title{
赤外吸収スペクトルによるポリカルボシラン1) 生成反応機構の検討
}

\author{
(1986 年 9 月 8 日受理)
}

市川 宏*・寺西春 夫块・石川敏功**

ポリカルボシラン (PCS) は Si-C 結合を骨格とする有機高分子であり，これを紡系，不融化，焼成 することにより炭化ケイ素絨維が得られる。PCS はポリジィチルシラン (PS) を $450^{\circ} \mathrm{C}$ 以上の高温で 熱分解転位反応を行なわせることによって得られる。この場合の反応機構はまた十分解明されていなか った。著者らは，この反応のさい副生する低分子のカルボシランについて，分別蒸留により区分し，そ のそれぞれについて赤外吸収スペクトルでその構造を同定した。その結果, $\mathrm{SiH}_{2}$ 基の存在の可能性を 見いだし，PCS の生成に拈ける橋かけによる高分子化の反応は，従来いわれてきた $\mathrm{SiH}$ 基によるるの ではなくて, $\mathrm{SiH}_{2}$ 基による反応が主として関与しているものと推定した。

\section{1 緒言}

炭化ヶイ素繊維の前駆物質であるポリカルボシラン（以下 PCS と略記する) は, ジクロロジメチルシランを出発原料とし，これ をナトリウムにより脱塩素反応を行なわせて得たポリジメチルシ ラン $\left(\left[\left(\mathrm{CH}_{3}\right)_{2} \mathrm{Si}\right]_{n}\right.$, 以下 PS と略記する $\left.{ }^{2)}\right)$ を高温で熱分解転位 反応を行なわせて合成したものである314!。この PCS はシルメチ レン $\left(-\mathrm{S}_{1}^{\prime} \mathrm{i}-\mathrm{C}_{1}^{\mathrm{C}}-\right)_{n}$ 骨格をもち, 分子量が 800 30000 の範囲の有 機ケイ素重合体である。炭化ケイ素織維はこれを紡系し, 不融化 したのち，不活性雲囲気中で $1300^{\circ} \mathrm{C} て ゙$ 焼成してつくられる。

この䋞維は高強度, 高弾性率をもっているらえ, $1000^{\circ} \mathrm{C}$ 以上の 高温度の空気中でも，その特性を保持する。したがって耐熱材料 として，またこれを用いてつくった繊維強化プラスチックス（以 下 FRP と略記する), 繊維強化金属 (以下 FRM と略記する), 緎維強化セラミックス（以下 FRC と略記する）などの複合材料 はすぐれた性能をもっているため, 宇宙航空用, 自動車用, スポ ーツ用品用の材料として大きな期待がもたれている。

この炭化ケイ素絨維の特性は，その前駆物質である PCS の構 造および特性に大さな影響を受げ。PCS の合成反応の機構4お よび構造については，矢島，岡村らにより報告されている。PS の高温熱分解による PCS の生成反応の機棈は、へキサメチルジ シラン 5) 7) の熱分解反応に基づくカルボシランの生成反応の機檏

日本カーボン株式会社研究所，221 横浜市神奈川区新浦 島町

** 日本カーボン株式会社, 104 東京都中央区八丁堀

1）本報に拄けるポリカルボシランの IUPAC 命名規則名は “poly[(methylsilanediyl)methylene]” である.

2）本報におけるポリジメチルシランのIUPAC 命名規則名は "poly(dimethylsilanediyl)" である.

3) S. Yajima, J. Hayashi, M. Omori, Chem. Lett., 1975, 931.

4) S. Yajima, Y. Hasegawa, J. Hayashi, M. Iimura, J. Mater. Sci., 13, 2569(1978).
を参考にして，ラジカル転位反応と推定されている(8)。また， PCS の構造については，ポリジメチルシランおよびテトラメチ ルシランから合成したPCS について検討されているき。しかし, PCS の生成反応の機構については，PS と PCS の構造から推定 しているにすぎず，反応機構の解明を目的とした実験報告はこれ までなされていない。これはPS から PCSへの合成反応は高温 での熱転位反応であって, 生成した PCS が幅広い分子量分布を むつ重合体であるため, 生成反応の機構の解明が困難であるから であった。

そこで本研究においては，PS から PCS の合成反応により得 られた反応生成物のらちで，とくに室温で液状の低分子量 PCS に着目し，これを分別蒸留で分離して，その主要成分について赤 外吸収スペクトルを行ない，その構造を同定し，PCS の生成反応 の機構の推定を試みた。

\section{2 実験}

2.1 ポリカルボシランの合成

ナトリウム $390 \mathrm{~g}$ をキシレン $2.5 l$ 中で $100^{\circ} \mathrm{C}$ 以上に加熱し, かきまぜて融解させた。そこにジクロロジメチルシラン $1066 \mathrm{~g}$ を㵜下し，100〜 $140^{\circ} \mathrm{C}$ で 12 時間，還流させながらかきまぜた結 果, 紫色の沈段が得られた。キシレンを河別したのち、この沈殿 にメタノールを加え，かきまぜて残留するナトリウムを処理し た。さらに水 $3 l$ を加え，かきまぜ，沪過することを 10 回くり 返して塩化ナトリウムを除去した。これを，まず熱風乾嬠機中

5) G. Fritz, J. Grobe, D. Kunmer, Adv. Inorg. Chem. Radiochem., 7, 349(1965).

6) H. Sakurai, R. Koh, A. Hosomi, M. Kumada, Bull. Chem. Soc. Jpn, 39, 2050(1966).

7) K.Siina, M. Kumada, J. Org. Chem., 23, 139(1958).

8）岡村清人，與谷川良雄，“炭化ヶイ素材料”，CMC (1985) p. 27.

9）長谷川良雄, 岡村清人, 日化, 1985，564. 
で， $120^{\circ} \mathrm{C} ， 5$ 時間の予備乾嬠を行なったのち，真空乾燥機中で $80^{\circ} \mathrm{C}, 5 \mathrm{mmHg}, 2$ 時間の乾燥を行なって，水分含有率 $0.1 \%$ の 白色粉末状のボリジメチルシラン $400 \mathrm{~g}$ を得た。

このよらにして得られたポリジメチルシラン $3000 \mathrm{~g}$ を容量 $20 l$ のオートクレーブに入れ，空気を窒素ガスで置換したのち，460 ${ }^{\circ} \mathrm{C}, 13$ 時間の密閉加圧反応を行なわせた。反応時の圧力は 0 最高 $68 \mathrm{~kg} \cdot \mathrm{cm}^{-2}$ (ゲージ仕) であった。

命却後、オートクレーブ中の生成ガスを放出し, 液状拈よび固 体状の反応生成物 $1950 \mathrm{~g}$ (収率 $65 \%$ ）を得た。ついでこの生成 混合物をへキサン $8 l$ に溶解し, 汇過したのち, へキサンを留去 してから, $260^{\circ} \mathrm{C}, 4 \mathrm{mmHg}$ で減圧蒸留を行なって, 淡黄色固体 の PCS $1260 \mathrm{~g}$ と液状留出物 $690 \mathrm{~g}$ を得た。収率はポリシメチル シランに対して，それぞれ 42 と $23 \%$ であった。

固体状 PCS については融点执よびゲル浸透クロマトグラフィ 一(以下 GPC と略記する) を測定した。また留出物については, ガスクロマトグラフィー分析を行ならとともに, 内径 $20 \mathrm{~mm}$, 高さ $500 \mathrm{~mm}$, 理論段数 20〜25 段の蒸留塔で，常圧または $3 \mathrm{mmHg}$ の減圧下で分別蒸留を行なって 15 種類の留分に分別 した。これらの留分について，それぞれ赤外吸収スペクトル分析， を行なった。

\section{2 测定方法}

PCS の融点はメトラー社製全自動融点测定装置 (PF-61 型) を使用し, 内径 $1 \mathrm{~mm}$ のガラス製キャピラリーに 325 メッシュ 以下の粉末試料を充媜密度 $0.54 \sim 0.57 \mathrm{~g} \cdot \mathrm{cm}^{-3}$, 高さ $4.0 \sim 4.5$ $\mathrm{mm}$ に充填し, $10^{\circ} \mathrm{C} \cdot \mathrm{min}^{-1}$ の昇温速度で光の透過度を測定した。 試料が融解し，光透過曲線が急激に上昇する変曲点の温度を融点 とした。

GPC 分析は東洋曹達(株)製高速液体クロマトグラフ (HLC801 型) を使用し，カラムは同社製 $\mathrm{G} 2000 \mathrm{H}$ および $\mathrm{G} 4000 \mathrm{H}$ を各 2 本ずつ直列につなぎ，検知器は示差屈折計を用いた。試料 は THF 溶液 (65 mg PCS $/ 3 \mathrm{ml} \mathrm{THF}$ ) とし, 流速 $1 \mathrm{~m} l \cdot \mathrm{min}^{-1}$, 圧力 $8 \mathrm{~kg} \cdot \mathrm{cm}^{-2}$ で測定した。平均分子量は標準ポリスチレンに より, 溶出量と分子量の関係を測定し, これに基ついて算出し た。
ガスクロマトグラフィーは島津製作所製 GC-6 A 型を使用し, カラムは SE-30, 長さ $3 \mathrm{~m}$ のものを用い, 検出器は熱伝導度検出 器 (TCD) を用いた。温度は $80 \sim 280^{\circ} \mathrm{C}$, 昇温速度 $10^{\circ} \mathrm{C} \cdot \mathrm{min}^{-1}$, キャリヤーガスとしでリゥムを $45 \mathrm{ml} \cdot \mathrm{cm}^{-1}$ 流し，測定した。 赤外吸収スペクトル分析は日本分光製赤外分光分析装置(TRA1 型）を使用し，ベンゼン補償法で，試料 $1 \mathrm{~g}$ をベンゼン $30 \mathrm{ml}$ に溶解した溶液について測定した。

\section{3 結果および考察}

PS の高温熱分解反応により得られた PCS の GPC クロマト グラムを図 1 に示す。この PCS の数平均分子量は 1470 であり, 標準ポリスチレンから推定すると，分子量は 800～30000 の広範 聿に分布している。融点は $210^{\circ} \mathrm{C}$ であった。

つぎに PCS の赤外吸収スペクトルを図 2 に示す。PCS の特性 吸収は $2100 \mathrm{~cm}^{-1}$ ( $\mathrm{Si}-\mathrm{H}$ 伸縮振動) と $1200 \mathrm{~cm}^{-1}\left(\mathrm{Si}-\mathrm{CH}_{3}\right.$ 対称 変角振動)の鋭いピークが観察され, シルメチレン結合 $\left(\mathrm{Si}-\mathrm{CH}_{2}-\right.$ Si）の特性吸収として $1360 \mathrm{~cm}^{-1}$ に $\mathrm{CH}_{2}$ の变角振動, 1020 $\mathrm{cm}^{-1}$ に $\mathrm{CH}_{2}$ の縦ゆれ振動がみられる。そのほか主要な吸収とし ては, $2990 \mathrm{~cm}^{-1}$ (C-H 非対称伸縮振動), $2920 \mathrm{~cm}^{-1}$ (C-H 対称 伸樎振動) および $830 \mathrm{~cm}^{-1}$ に $\mathrm{Si}-\mathrm{CH}_{3}$ の横ゆれ振動の大きなピ

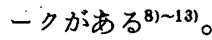

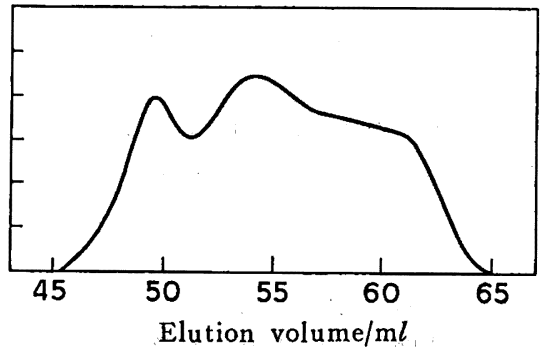

Fig. 1 Elution curve of GPC on the polycarbosilane

Detector : RI

Column : Toyo Soda, G $2000 \mathrm{H} \times 2+\mathrm{G} 4000 \mathrm{H} \times 2$

Flow rate $: 1 \mathrm{ml} \cdot \mathrm{min}^{-1}$

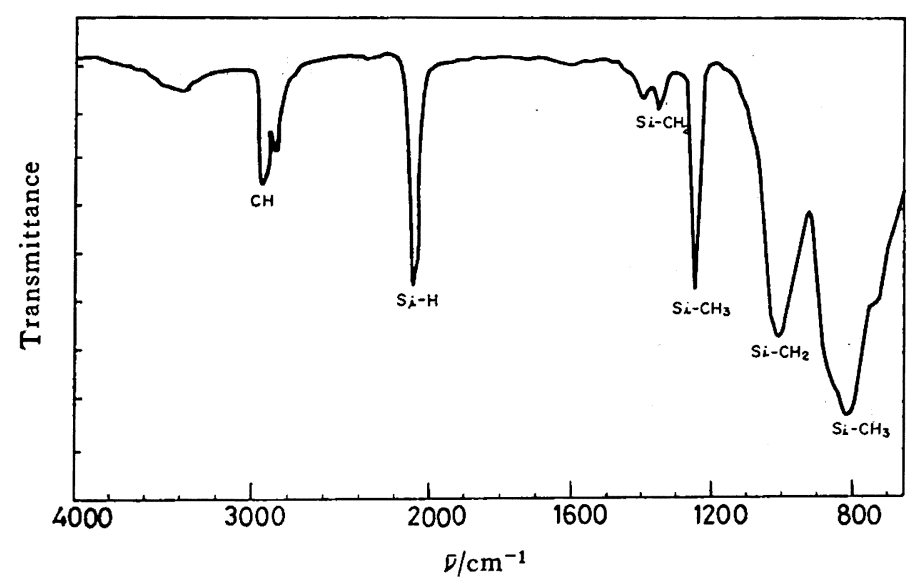

Fig. 2 IR spectrum of the polycarbosilane (solid)

10) W. A. Kriner, J. Org. Chem., 29, 1601(1964).
11) E. Carberry, R. West, J. Am. Chem. Soc., 91, 5440 (1969). 


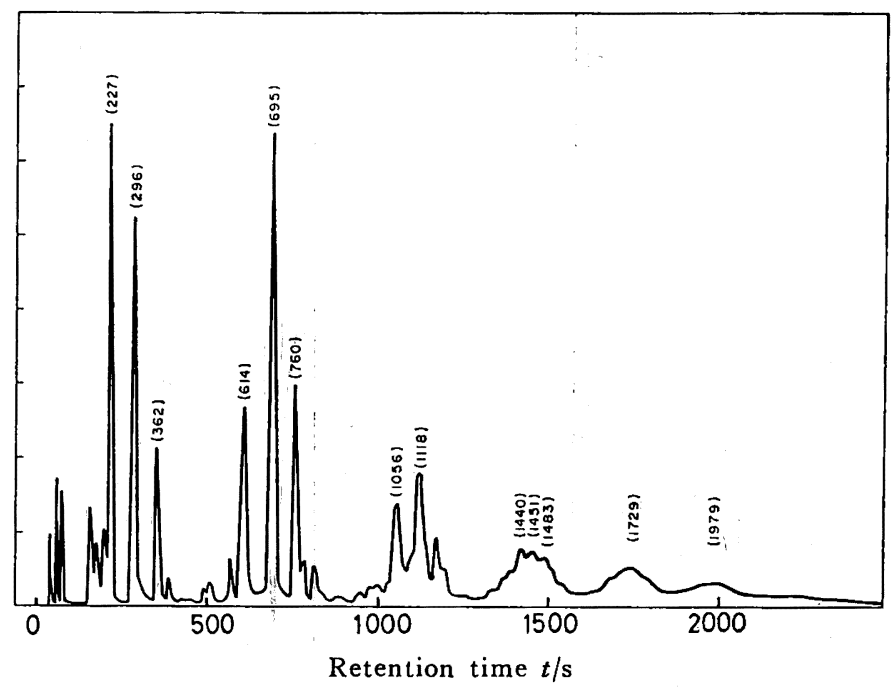

Fig. 3 Gas chromatographic trace of the liquid polycarbosilane which was obtained by vacuum distillation from the polycarbosilane mixture

( ) : Retention time ( $s$ )

留分についてはガスクロマトグラフィーで棈成成分を分析し た。その結果を図 3 に示す。分別された成分の数は 31 ときわめ て多い。この成分を分類すると， 5 種類の区分に大別できる。各 区分の保持時間の範囲および成分数，ピーク面積から算出した含 有比率を表 1 亿示す。

ついで, この留分を分別蒸留により 15 種類に分別した。その 主要な成分についての沸点範囲および分別量（wt\%）を表 2 に示 す。成分番号 7 以上のものは $3 \mathrm{mmHg}$ の減圧下で蒸留を行なっ たので， 1 気压の場合に換算した值で沸点を表示した。これらの 成分のらち主要なるのについて，さらにガスクロマトグラフィー で分析した結果表 3 に示すように, 沸点 $158^{\circ} \mathrm{C}$ 以下の成分番号 6 以下のむのはガスクロマトグラフィーでの区分 I，成分番号 7 9 は区分 II，成分番号 11〜15 は区分III，残留物は区分 $\mathrm{N}$ 扰よび Vに相当することが明らかになった。

分別した主要な留分の赤外吸収スペクトルを図 4 〜 6 に示す。

Table 1 Retention time, numbers of the peak and area\% on the gaschromatographic trace of the liquid polycarbosilane

\begin{tabular}{cccc} 
Partition & $\begin{array}{c}\text { Retention time } \\
t / \mathrm{s}\end{array}$ & $\begin{array}{c}\text { Numbers of } \\
\text { the peak }\end{array}$ & Area\% \\
\hline I & $172 \sim 362$ & 7 & 40.7 \\
II & $514 \sim 812$ & 8 & 20.3 \\
III & $995 \sim 1197$ & 6 & 12.2 \\
N & $1330 \sim 1568$ & 5 & 9.2 \\
V & $1633 \sim 2169$ & 5 & 12.9 \\
Total & & 31 & 95.3
\end{tabular}

a) Area $\%$ indicates the percentage by area on the gaschromatographic trace.

12) D. R. Weyenberg, L. E. Nelson, J. Org. Chem., 30, 2618(1965).

13) W. R. Bamford, J. C. Lovie, J. A. C. Watt, J. Org. Chem., $C$, 1966, 1137.
Table 2 Boiling point and fraction of the distillate from liquid polycarbosilane

\begin{tabular}{ccc}
$\begin{array}{c}\text { Distillate } \\
\text { No. }\end{array}$ & $\begin{array}{c}\text { bp } \\
\left(\theta /{ }^{\circ} \mathrm{C}\right)\end{array}$ & $\begin{array}{c}\text { Fraction } \\
(\text { wt } \%)\end{array}$ \\
\hline 2 & $74 \sim 77$ & 2.3 \\
3 & $78 \sim 98$ & 3.1 \\
4 & $101 \sim 105$ & 8.2 \\
5 & $110 \sim 138$ & 12.5 \\
6 & $140 \sim 158$ & 3.6 \\
7 & $170^{a)}$ & 13.1 \\
8 & 210 & 5.1 \\
9 & 230 & 12.8 \\
11 & 250 & 1.0 \\
12 & 255 & 5.5 \\
15 & 290 & 7.1 \\
Dregs & - & 18.6
\end{tabular}

a) Distillates No. $7 \sim 15$ were obtained by vacuum distillation at $3 \mathrm{mmHg}$.

The boiling points are the $760 \mathrm{mmHg}$ equivalents.

Table 3 The percentage by area on the gaschromatographic trace of the distillates from the liquid polycarbosilane

Percentage by area (\%)

\begin{tabular}{|c|c|c|c|c|c|}
\hline $\begin{array}{c}\text { Partition } \\
\text { Retention time } \\
(t / \mathrm{s}) \\
\end{array}$ & \multirow[t]{2}{*}{$\stackrel{172}{\sim} \underset{ }{\mathrm{I}}$} & \multirow[t]{2}{*}{$\stackrel{\text { II }}{\sim} \underset{\sim}{\sim}$} & \multirow[t]{2}{*}{$\begin{array}{c}\text { III } \\
955 \\
\sim 1197\end{array}$} & \multirow[t]{2}{*}{$\begin{array}{c}\mathbf{N} \\
1330 \\
\sim 1568\end{array}$} & \multirow[t]{2}{*}{$\begin{array}{c}\mathrm{V} \\
1633 \\
\sim 2169 \\
\vdots\end{array}$} \\
\hline Distillation No. & & & & & \\
\hline 4 & 95.5 & 1.2 & - & - & - \\
\hline 5 & 91.2 & 6.3 & - & $\pi$ & - \\
\hline 6 & 83. 6 & 13. 1 & - & $\therefore$ & - \\
\hline 7 & 20.7 & 75.5 & 1.1 & - & - \\
\hline 9 & 8. 6 & 85.3 & 3.2 & - & - \\
\hline 11 & 1.3 & 26.3 & 68.5 & - & $\therefore$ \\
\hline 15 & - & 10.8 & 75.6 & 8.6 & - \\
\hline Dregs & - & 2.1 & 10.6 & 36.1 & 45.3 \\
\hline
\end{tabular}




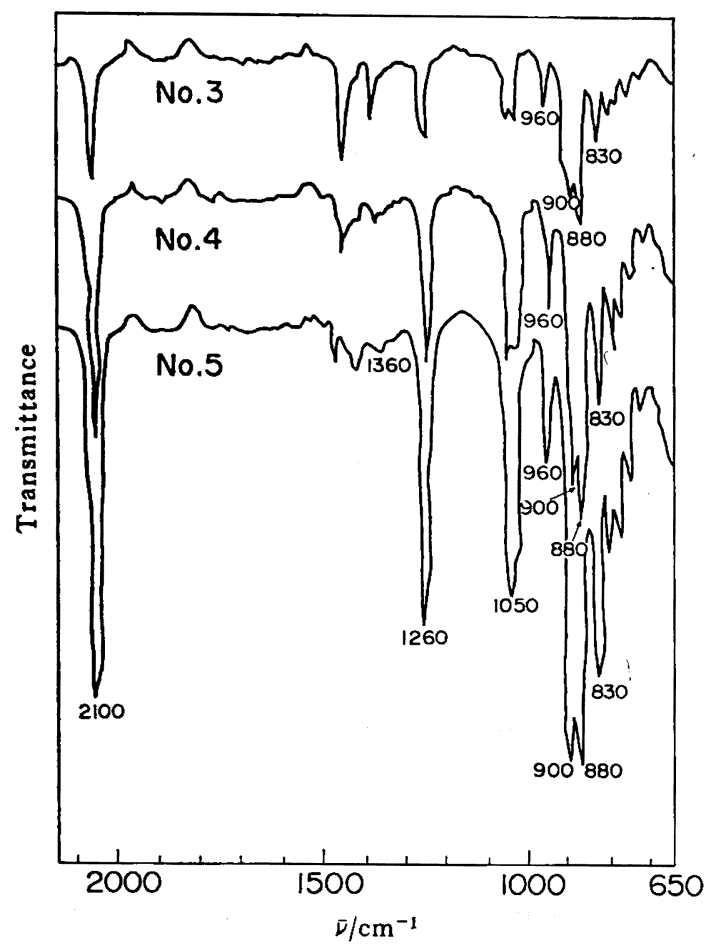

Fig. 4 IR spectra of the fractions (No. 3, 4, 5) from the liquid polycarbosilane

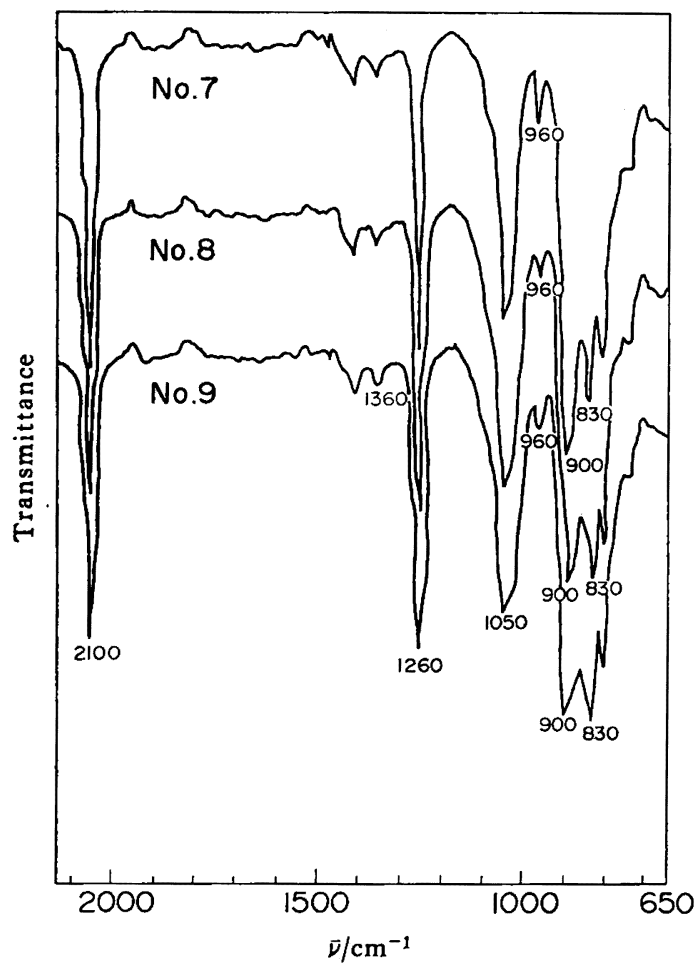

Fig. 5 IR spectra of the fractions (No. 7, 8, 9) from the liquid polycarbosilane

留分のスベクトルはいずれも，2100, $1260,1360,1020,830 \mathrm{~cm}^{-1}$ にPCS と同一の吸収ピークがあり, PCS 特有の $\mathrm{Si}-\mathrm{CH}_{2}-\mathrm{Si}$ 結 合の吸収 $\left(1360,1020 \mathrm{~cm}^{-1}\right)$ が認められることからポリカルボン

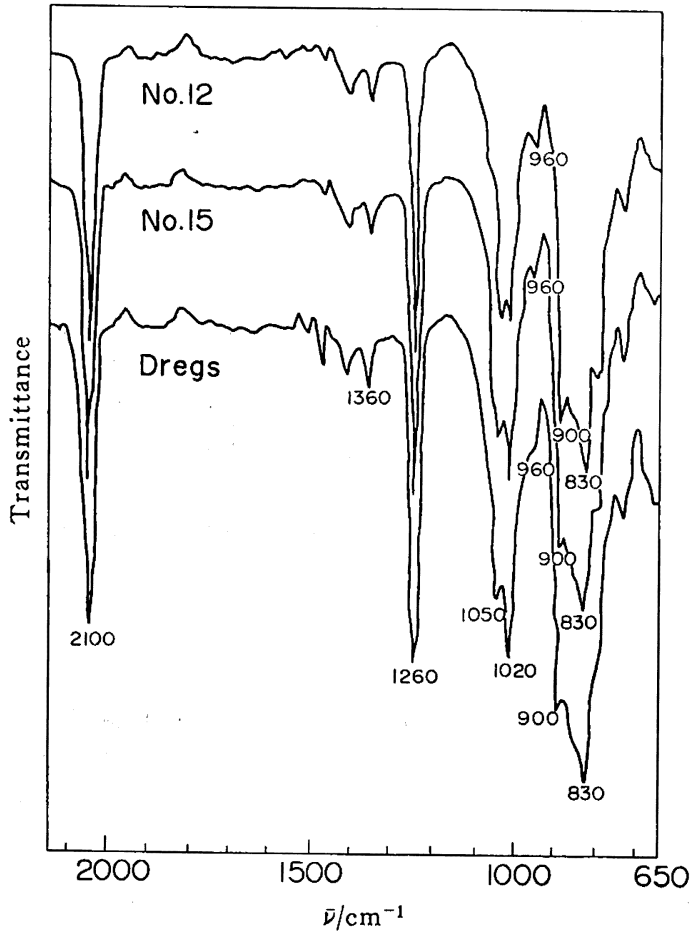

Fig. 6 IR spectra of the fractions (No.12,15) and dregs from the liquid polycarbosilane

ランであることがわかる。しかし，留分の場合は PCS の場合と は異なり，1000 $\mathrm{cm}^{-1}$ 以下の低波数側では吸収ピークが多く認め られる。これは留分の分子量が比較的小さく, 含まれている成分 の数む少ないためと考えられる。

PS の熱分解転位反応により生成するポリカルボシランの骨格 および官能基について, 赤外吸収スペクトルの低波数側で観察さ れる一般的な吸収は $\mathrm{Si}-\mathrm{H}, \mathrm{Si}-\mathrm{CH}_{3}$ の変角振動および $\mathrm{Si}-\mathrm{C}$ の伸 縮振動である。このうち $\mathrm{Si}-\mathrm{H}$ 結合の振動の場合, $\mathrm{SiH}$ 基の変角 振動は $770 \sim 900 \mathrm{~cm}^{-1}, \mathrm{SiH}_{2}$ 基では $940 \sim 960 \mathrm{~cm}^{-1}$ にはさみ振 動, $820 \sim 880 \mathrm{~cm}^{-1}$ に綎ゆれ振動, $\mathrm{SiH}_{3}$ 基では $950 \mathrm{~cm}^{-1}$ に非対 称変角振動がある ${ }^{14) ~ 16) 。 ~ 。 ~}$ $\mathrm{SiCH}_{3}$ 基拈よび $\mathrm{Si}\left(\mathrm{CH}_{3}\right)_{2}$ 基の横ゆれ振動がそれぞれ 780〜810, $795 \sim 830 \mathrm{~cm}^{-1}$ にある ${ }^{(4) ~ 16)}$ 。 Si-C 結合の伸縮振動は非対称が 700 $\pm 20 \mathrm{~cm}^{-1}$, 対称が $625 \pm 15 \mathrm{~cm}^{-1}$ と比較的低波数側にある ${ }^{151}$ 。

ここで図 4 における留分 $2,3,4$ の $1000 \mathrm{~cm}^{-1}$ 以下の特徽的な 吸収は $830,880,900,960 \mathrm{~cm}^{-1}$ である。このうち $960 \mathrm{~cm}^{-1}$ の中 程度の吸収は, 分別したすべての留分に認められる。 $960 \mathrm{~cm}^{-1}$ 付 近の吸収は $\mathrm{SiH}_{2}$ 基の $\mathrm{Si}-\mathrm{H}$ のはさ文振動と $\mathrm{SiH}_{3}$ 基の非対称 変角振動が該当するが, PS の熱分解反応からたと立 $\mathrm{SiH}_{3}$ 基が 生成したとしても $465^{\circ} \mathrm{C}$ という高温の状態で反応性の高い $\mathrm{SiH}_{3}$ 基が反応せずに残存することは考劣にくいため,この吸収は $\mathrm{SiH}_{2}$ 基のはさみ振動であると推定した。 $\mathrm{SiH}_{2}$ 基は $820 \sim 880 \mathrm{~cm}^{-1}$ に

14）熊田諴, 大河原六郎編, “有機ヶイ素化学”, 梖费店(1959) p. 319 .

15）大河原六郎, 山崎 稔, “化学の領域增刊 45 号. 赤外線吸 収スペクトル第 13 集”, 南江堂 (1961) p. 127.

16）中島 功; 有我欣司編, “けい素樹脂”, 日刊工業新聞社 (1970) p. 217. 
Table 4 The absorbance ratio $\left(A_{2100} / A_{1260}\right)$ in IR spectra on the distillates from the liquid polycarbosilane

Distillate No.

\begin{tabular}{cccccccccc} 
& 2 & 3 & 4 & 7 & 8 & 9 & 12 & 15 & Dregs \\
\hline$A_{2100} / A_{1260}$ & 1.71 & 1.48 & 1.25 & 1.11 & 0.97 & 0.95 & 0.91 & 0.94 & 0.89
\end{tabular}

繸ゆれ振動をともならが，図4 亿拝ける $880 \mathrm{~cm}^{-1}$ の吸収はこれ に相当するものと考えられる。

留分 $3 \sim 5$ は沸点 $78 \sim 138^{\circ} \mathrm{C}$ の籁囲にあり, 二量体のへキサメ チルジシルメチレン ${ }^{17)}$ の沸点が $134^{\circ} \mathrm{C}$ であることから、これらの ガスクロマトグラフィー分別区分 I に相当する留分は, 化学式 〔a]および $[b]$ で示すような鎖状二量体であると考えられる。<smiles>C[SiH](C)C[SiH](C)C</smiles>

$[a]$<smiles>C[SiH](C)C[Si](C)(C)C</smiles>

図 4 において，900と $880 \mathrm{~cm}^{-1}$ の四収は完全に分離しており, これも二量体であるテトラメチルシロキサン15)18)における吸収 と類似している。

図 5 で示した留分 $7 \sim 9$ の沸点範囲 $170 \sim 230{ }^{\circ} \mathrm{C}$ の赤外吸収ス ペクトルでは $900,880 \mathrm{~cm}^{-1}$ の吸収が完全に分離しておらず, $700 \sim 830 \mathrm{~cm}^{-1}$ の吸収が簡単になっている。三量体のオクタメチ ルトリシルメチレン17119, へキサメチルシクロトリシルメチレ ン1720) の沸点がそれぞれ $206,201^{\circ} \mathrm{C}$ であることを考虑すると， 区分II の留分は，たとえば，化学式 $[c] ，[d] に$ 示すよらな環 状または鎖状の三量体のポリカルボシランと推定される。

図 6 に打ける留分 11,15 ，釜残の赤外四収スペクトルでは 830 $\mathrm{cm}^{-1}$ の吸収が非常に強く, $960,900,880 \mathrm{~cm}^{-1}$ の吸収は減少して いる。

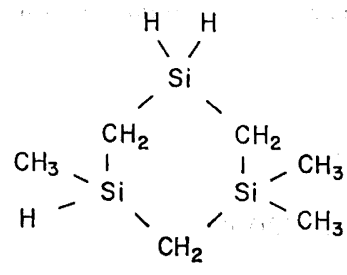

[c]<smiles>[1H][Si](C)(C)C[SiH](C)C</smiles>

[d]
一方, 1050 と $1020 \mathrm{~cm}^{-1}$ の吸収が完全に分離すると同時に $1020 \mathrm{~cm}^{-1}$ の吸収が増大する傾向にある。また， $1360 \mathrm{~cm}^{-1}$ の吸 収む增大しており，固体状 PCS の吸収に近くなっている。これ はシルメチレン結合の骨格が增大しているためと考えられる。

17）能田 誠, 大河原六郎編, “有機ヶイ素化学”, 椇書店(1959) p. 176.

ヘキサメチルシシシルメチレン: $\left(\mathrm{CH}_{3}\right)_{3} \mathrm{SiCH}_{2} \mathrm{Si}\left(\mathrm{CH}_{3}\right)_{3}$.

18）テトラメチルシロキサン: $\mathrm{HSi}\left(\mathrm{CH}_{3}\right)_{2} \mathrm{OSiH}\left(\mathrm{CH}_{3}\right)_{2}$.

19) オクタメチルトリシルメチレン: $\left(\mathrm{CH}_{3}\right)_{3} \mathrm{SiCH}_{2} \mathrm{Si}\left(\mathrm{CH}_{3}\right)_{2}$. $\mathrm{CH}_{2} \mathrm{Si}\left(\mathrm{CH}_{3}\right)_{3}$.

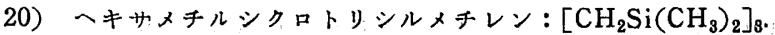

図 4〜6で PCS の留分の吸収ピークの変化をまとめてみる と，960と $880 \mathrm{~cm}^{-1}$ の吸収は高沸点になるにしたがい，ほぼ同 じ傾向で減少している。これはさきに推定したように，両ビーク とも $\mathrm{SiH}_{2}$ 基に起因する $\mathrm{Si}-\mathrm{H}$ 変角振動である可能性を示してい る。また，900と $830 \mathrm{~cm}^{-1}$ の吸収ピークの変化を比較してみる と, 低沸点成分では $900 \mathrm{~cm}^{-1}$. の吸収は $830 \mathrm{~cm}^{-1}$ の吸収にくら べて大きいが，高沸点になるにしたがって減少し，留分 8 では ぼ同じであるのに対して, 留分 9 では $830 \mathrm{~cm}^{-1}$ の吸収ピークが 大きくなっている。

一方, $2100 \mathrm{~cm}^{-1}\left(\mathrm{Si}-\mathrm{H}\right.$ 伸縮振動) 扰よび $1260 \mathrm{~cm}^{-1}\left(\mathrm{Si}-\mathrm{CH}_{3}\right.$ 対称変角振動）の関係を吸光度比 $A_{2100} / A_{1260}$ でみると．表 4 に示 すように，高沸点成分になるほと減少し，留分 8 では 0.97 と両 ピークは同じになり，留分 8 より高沸点の成分では $1260 \mathrm{~cm}^{-1}$ の 吸光度が大きくなる。この傾向は 900 と $830 \mathrm{~cm}^{-1}$ の関係とほほ 一致する。このことから 900 は $2100 \mathrm{~cm}^{-1}$ に対応する $\$ \mathrm{i}-\mathrm{H}$ の 変角振動と推定できる。また, $830 \mathrm{~cm}^{-1}$ は $\mathrm{Si}-\mathrm{CCH}_{3}$ の横ゆれ振動 が主要な吸収である。

以上から， $\mathrm{SiH}$ 基を含む PCS 留分の構造単位の特性受収はつ ぎのように整理することができる。

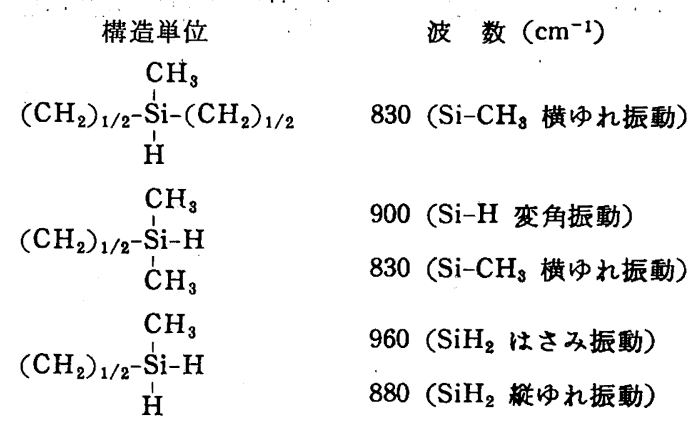

これら PCS 合成反応で副生した留分の構造は PCS の生成反 応過程と密接な関係があると考えられる。オートクレーブ中にお ける PS の高温高压反応のさいの温度を $460^{\circ} \mathrm{C}$, 圧力を 60 気圧 と仮定した場合, 沸点約 $240^{\circ} \mathrm{C}(1 \mathrm{~atm})$ 以下の低分子のカルボシ ランは気相として存在し, $250^{\circ} \mathrm{C}$ 以上の高沸点のカルボシランは 液相中に存在するものと考えられる。このことから留分 9 以下の 沸点のカルボシランは気相で平衡関係にあり，留分 11 以上の沸 点のカルボシランは液相側で平衡関係にあるものと考えられる。

これらの留分の中に $\mathrm{SiH}_{2}$ の存在の可能性が認められたこと は, $\mathrm{SiH}_{2}$ 基が橋かけ反応による $\mathrm{Si}-\mathrm{CH}_{2}-\mathrm{Si}$ 結合の生成に関与し ている可能性があるものと推定される。矢島らによれば4)(21!, PCS 生成反応の機構は, 最初に PS のラジカル転位反応（反応式 (1)〜 (4)）によりシルメチレン結合をすつカルボシランが生成 し, ついで $\mathrm{SiH}$ 基による脱水素縮合反応（反応式（5)）により 高分子化するものと推定している。しかし， $\mathrm{SiH}_{2}$ 基が存在した

21）矢島聖使，工業材料，27(5)，99(1979). 


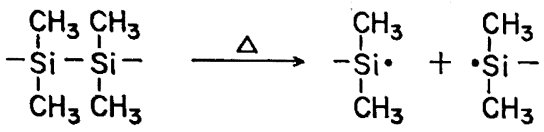

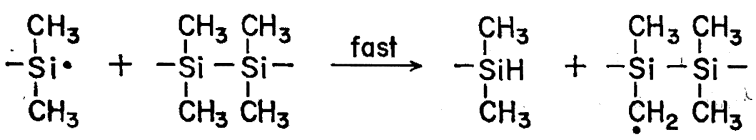
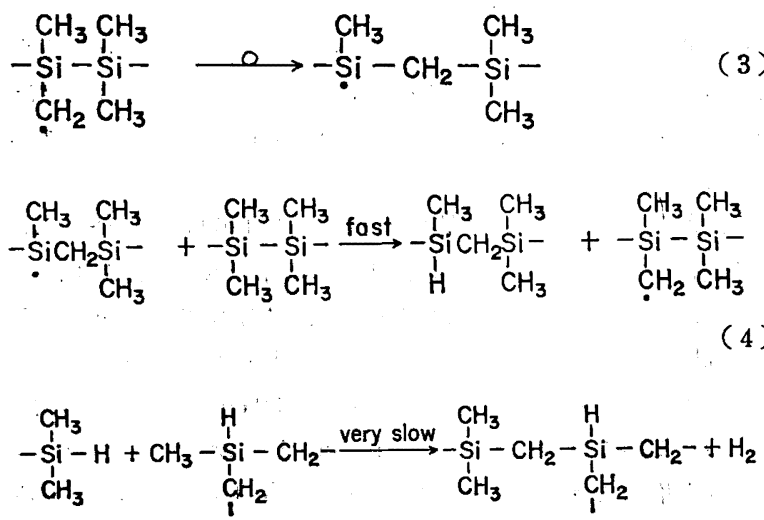

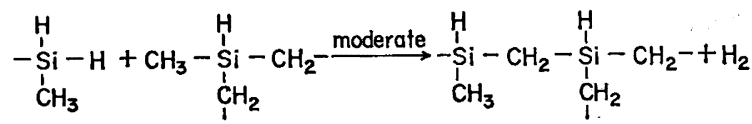

場合, $=\mathrm{SiH}_{2}$ は $\equiv \mathrm{SiH}$ にくらべて反応性が高い22)ため反応式( 5 ) の $\mathrm{SiH}$ 基による脱水素縮合反応に優先して, $\mathrm{SiH}_{2}$ 基による脱水 素樎合橋かけ反応（反応式（6)）が起こるものと考えられる。 オートクレーブ中, $460^{\circ} \mathrm{C}$ の高温での長時間 (13 時間) の反応

22）熊田 誠, 大河原六郎編, “有機 ケイ素化学”, 椇曺店 (1959) p.65.
により得られた PCS 中に多量の $\mathrm{SiH}$ 基が存在することからも， $\mathrm{SiH}$ 基が関与する反応はきわめて羊いことが推定される。これに くらべて, $\mathrm{SiH}_{2}$ 基は反応のさい，気相状態での低沸点留分中に は存在するものの；高沸点になるほど減少し，反応中夜相で存在 する高沸点留分では，ごくわずかしか存在しないといらことは，

$\mathrm{SiH}_{2}$ 基の反応への関与を裏づけているとい方よう。

したがって，転位反応で生成したPCS の高分子化は反応式 （6）に示すような $\mathrm{SiH}_{2}$ 基による橋かけ反応が主反応になって いるものと考吕れる。

\section{4 結 論}

オートクレーブ中に拈ける PS の高温高王熱分解転位反応によ り得られた低分子のカルボシランを分別し，赤外吸収スペクトル によりその構造を推定した結果，つぎのことが明らかになった。

（1） PCS 合成反応のさい生成する低分子のカルボシランは 大別するとメチルシルメチレンの二量体，三量体および四量体以 上の三つに区分できる。

（2）低分子のカルボシランは赤外吸収スペクトルの波数 $1000 \mathrm{~cm}^{-1}$ 以下において, PCS については観察されないいくつか の特性吸収をむっている。その吸収は $960,880 \mathrm{~cm}^{-1}$ における $\mathrm{SiH}_{2}$ のはさぬ振動と縦ゆれ振動扰よび $900 \mathrm{~cm}^{-1}$ の $\mathrm{SiH}$ 基の変 角振動と推定される。

（3）低分子ポリカルボシラン中に $\mathrm{SiH}_{2}$ が存在することか ら, PCS の生成反応の機構は, PS のラジカル転位反応により生 成したポリカルボシランの橋かけ高分子反応によるものであっ て，そのさい $\mathrm{SiH}_{2}$ 基による脱水素縮合反応が主反応である.と推 定される。

PCS の生成反応は本報で述べた反応機構以外にも，数多くの 複雑な反応が行なわれている可能性がある。本研究は赤外吸収ス ペクトルによる一考察であるが, さらに NMR, ESR, GC-MS, GC-IR などによる分析を行なって確認する必要がある。

本研究にあたり，御指導，お力添えをいたたきました故川角一 久氏に深く感謝いたします。

(1984 年 9 月 13 日, UI th International Symposium on Organosilicon Chemistry Kて発表)

\title{
Discussion on the Formation Mechanism of Polycarbosilane by IR Spectroscopy
}

\author{
Hiroshi Ichikawa*, Haruo Teranishi** and Toshikatsu Ishikawa** \\ Nippon Carbon Co., Ltd., Research \& Development Laboratory ; Shin-urashima-cho, \\ Kanagawa-ku, Yokohama-shi 221 Japan \\ ** Nippon Carbon Co., Ltd.; Hatchobori, Chuo-ku, Tokyo 104 Japan
}

Polycarbosilane (PCS) is organic polymer which consists of the skeleton of Si-C bond. $\mathrm{SiC}$ fiber is produced from PCS by the processes of spinning, curing and heat treatment. PCS is obtained from polydimethylsilane (PS) through thermal decomposition and rearrangement reaction caused by heat treatment at a temperature above $450^{\circ} \mathrm{C}$. Several reaction mechanisms in which PS was converted into PCS, have been reported. In these reports the reactions were considered to be radical rearrangement, by which $\mathrm{Si}-\mathrm{Si}$ bonds are converted into $\mathrm{Si}-\mathrm{CH}_{2}-\mathrm{Si}$ bonds, and dehydrogenation condensation between $\mathrm{SiH}$ bond and $\mathrm{SiCH}_{3}$ bond. Details and mechanism of the reaction, however, have not yet been clarified. 
In this work, the distillates with low molecular weight, which were obtained from PS through thermal reaction, were fractionated into 15 fractions (Table 2), and by the use of their IR absorption spectra, the reaction mechanism was discussed. The IR spectra of all the fractions obtained showed the peaks indicating $\mathrm{Si}-\mathrm{CH}_{2}-\mathrm{Si}$ bonds, and in a region below $1000 \mathrm{~cm}^{-1}$, there were observed some of the peaks (Figs. 4, 5,6), which were not observed in PCS. Since the results of the IR spectra of the low molecular carbosilane suggested the presence of $\mathrm{SiH}_{2}$ bond, it was considered that the main reaction was the dehydrogenation condensation between $\mathrm{SiH}_{2}$ and $\mathrm{SiCH}_{3}$ in the crosslinking reaction of PCS. 